\title{
Effects of Progressive Muscle Relaxation on Academic Stress in Students
}

\author{
Arman Bin Anuar \\ Guidance and Counseling, Universitas Negeri Makassar, Indonesia \\ Email: arman.anward3@gmail.com \\ Muhammad Anas \\ Guidance and Counseling, Universitas Negeri Makassar, Indonesia \\ Email: anas.maliki.am@gmail.com \\ Sulaiman Samad \\ Guidance and Counseling, Universitas Negeri Makassar, Indonesia \\ Email: essamad@gmail.com
}

(Received: 25-May-2019; Reviewed: 15-November-2019; Accepted: 22-December-2019; published: 29-December-2019)

\begin{abstract}
This study aims to describe (1) the practice of progressive muscle relaxation (PMR) for academic stress in students; (2) the levels of students' academic stress before and after the treatment of PMR; and (3) the effects of PMR on students' academic stress. This quantitative-based study used a quasi-experimental design and a non-equivalent control groups design. The sample of the study was 40 students of the eleventh grade identified with high level of academic stress. Data were collected through observation and academic stress scale, analyzed using descriptive analysis technique and statistics analysis techniques with paired sample t-test and independent sample t-test. Results of the study show that (1) PMR was performed in accordance with the procedures; (2) students had high level of academic stress before performing PMR, but had low academic stress after performing PMR; and (3) PMR had a positive impact on students' academic stress, meaning that it can be used to reduce academic stress in students.
\end{abstract}

Keywords: Relaxation Techniues; Progressive Muscle Relaxation; Academic Stress; Counseling.

\begin{abstract}
Abstrak. Tujuan penelitian untuk mengetahui (1) gambaran pelaksanaan teknik relaksasi otot progresif terhadap stres belajar siswa (2) gambaran tingkat stres belajar siswa sebelum dan sesudah perlakuan teknik relaksasi otot progresif (3) pengaruh teknik relaksasi otot progresif terhadap stres belajar siswa. Jenis penelitian kuantitatif dengan rancangan quasy eksperimental dengan non-equivalent Control Grup Design. Sampel penelitian adalah siswa kelas XI yang berjumlah 40 orang yang teridenfikasi mengalami stress belajar tinggi. Pengumpulan data diperoleh dengan menggunakan observasi dan skala stress belajar siswa, kemudian dianalisis dengan menggunakan analisis deskriptif dan analisis statistik uji paired sample t-test dan uji independent sample t-test. Hasil penelitian menunjukan (1) gambaran pelaksanaan teknik relaksasi otot progresif terhadap stress belajar siswa dilaksanakan sesuai dengan prosedur yang sudah dirancang dengan beberapa tahapan pelaksanaan (2) gambaran tingkat stress belajar siswa sebelum diberikan teknik relaksasi otot progresif berada pada kategori tinggi, dan setelah diberikan teknik relaksasi otot progresif tingkat stress belajar siswa berada pada kategori rendah (3) teknik relaksasi otot progresif berpengaruh positif terhadap stres belajar siswa. Hal ini menunjukan bahwa teknik relaksasi otot progresif dapat digunakan untuk mengatasi stres belajar siswa
\end{abstract}

Kata kunci: Teknik Relaksasi; Relaksasi Otot Progresif; Stres Belajar Siswa; Konseling. 


\section{INTRODUCTION}

Full-day school system requires students to study at school from morning to late afternoon (Arioka, 2018). It aims to develop students' potentials, interests, talents and creativity that encompass cognitive, affective and psychomotor aspects; thus, full-day school does not mean adding learning materials, but adding hours to build students' characters instead (Sari \& Falah, 2018). Full-day school is challenging for students since it demands physical and psychological readiness. If students are not ready, they will suffer from boredom or struggle with heavy burden (stress) (Baharun \& Alawiyah, 2018).

People from different ages, adults, adolescents, and even children, can suffer from stress with various causes; one of which is study ( $\mathrm{Yu} \& \mathrm{Su}$, 2019; Ribeiro et al., 2018; Al-Gamal, Alhosain, \& Alsunaye, 2018; Pitt et al., 2018). Studyrelated stress is defined as pressures students face in the academic setting (Aryani, 2016). Academic stress is the condition in which students cannot meet academic-related demands and perceive them as disturbances (Barseli \& Ifdil, 2018; Rahmawati, 2017).

A study by Suryono, Triyono, \& Handarin (2016) showed that the contributing factors to academic stress in students are (1) too many lessons in a day, plus tutoring outside of school; (2) heavy workload of homework; (3) parental pressures and demands to excel at school; (4) no opportunities to associate with peers; and (5) no interests in particular subjects and teachers. On the other hand, Hidayat \& Sahruddin (2016) explain that academic stress can result in depression if it is not handled properly; thus, students must deal with academic stress immediately.

Results of preliminary observation and interviews with school counselors and homeroom teachers from 19 February to 21 February 2018 in SMA Negeri 8 Makassar indicated that some students in the eleventh grade were suffering from academic stress. The results of the distribution of academic stress scale adapted from Idris (2018) to 315 students, 115 students were indicated to suffer from academic stress in which 40 students were in the category of high level of academic stress; 45 students in the category of moderate level; and
30 students in the category of low level. According to school counselors, students experienced academic stress due to particular subjects such as mathematics, English, economics, chemistry and physics.

One of the counseling efforts to reduce academic stress in students is PMR. Studies have demonstrated that PMR can reduce academic stress effectively (Hidayat \& Ilyas, 2019; Utami \& Nasution, 2018; O'Donnell, Patrick, \& Linda, 2019). PMR is deep relaxation technique that does not require imagination, perseverance or suggestion (Erford, 2016). PMR is a skill that can be learned by anyone and used to reduce or release the tension and to derive comfort without depending on external things or subjects. PMR can be used to control anxiety, stress or tension (Gangadharan \& Madani, 2018; O’Donnell \& Dunlap, 2019; Chitra, 2018; Tollefson et al., 2018; Resti, 2014)

PMR is an easy, simple and widely used relaxation technique. The relaxation procedure can be practiced in two steps: tightening a group of muscles and releasing the tension while focusing on how the muscle group becomes relaxed and the tension is released (Maghfirah, 2015).

Progressive relaxation does not require imagination, but needs a focus on the muscle group activity by identifying the tightened muscle then releasing the tension to experience a relaxing sensation (Pratama, 2017; Merakou, et al., 2019; Karyo \& Saraswati, 2017). However, according to Corey (2015), PMR employs a series of physical movement in order to relax and give a comfortable effect to the whole body. Relaxation is one of self-management techniques based on how sympathetic and parasympathetic nervous system works. Relaxation technique has become increasingly popular since it is proven effective in reducing tension and anxiety (Tyani, 2015).

A study by Nurcahyani \& Lutfi (2016) indicated that relaxation technique was effective to relieve academic stress in high school students. However, only five students took part in the study and there was no control group. Meanwhile, the present study involved 40 students and had an experiment group and a control group. Thus, different results of the study on the academic stress in students due to relaxation technique are expected. 


\section{METHODS}

This quantitative-based study used a quasi-experimental approach with nonequivalent control groups design. The study was conducted in SMA Negeri 8 Makassar with the total population of 115 students identified with academic stress. Using purposive sampling technique, 40 students were chosen and divided into two groups: 20 students in the experimental group and 20 students in the control group. Data were collected using observation and an academic stress scale developed from previous scale by Idris (2018), which was then tested for validity by two guidance and counseling experts and one school counselor as a practitioner. Data analysis was conducted by descriptive analysis and statistics analysis using paired sample t-test and independent sample t-test.

\section{RESULTS AND DISCUSSION}

1. Pogressive muscle relaxation to reduce academic stress in the students of the eleventh grade in SMA Negeri 8 Makassar

PMR in relation to students' academic stress was conducted in accordance with the several stages of the procedures. It could directly release the tension in the joint muscles, which was highly useful for students to reduce their stress. The control group was not given the chance for PMR as a treatment, but given an information service. On the other hand, the experiment group was given a treatment of PMR.

The following are the steps of PMR: (1) Step 1: to exercise hand muscles. First, draw a hand into a fist while feeling the tension. Release the fist slowly and feel the relaxation for 20 seconds. Clenching left hand is performed twice to distinguish between muscle tension and physical relaxation. Then, do step 1 for the right hand; (2) Step 2: to exercise the back of the hand muscles. First, bend both arms back on the wrist to tighten the muscles of the back and forearms. Fingers face the ceiling. (3) Step 3: To exercise biceps (the large muscles at the front of upper arm). Draw both hands into fists, then pull the fists to the shoulder to tighten the biceps; (4) Step 4: To relax the shoulder muscles by rising up shoulders towards both ears and focusing the attention of the movement on the contract tension in the shoulders, upper back and neck; (5) Steps 5 and 6: to relax facial muscles (muscles in the forehead, eyes, jaws and mouth).
First, tighten the muscles in the forehead until the muscles become tensed. Then, shut the eyes tightly until the muscles around the eyes are tightened and tensed; (6) Step 7: to relax the tension in the jaw muscles. Clasp the jaws while biting the teeth to tense the muscles in the jaws; (7) Step 8: to relax the muscles of the mouth. Tighten the lips and notice the feeling of the tension around the mouth; (8) Step 9: to relax the muscles of the front and back neck. Start with the muscles in the back neck, and then continue to the muscles of the front neck. Lay down the head to rest. Press the head on the surface of the seat cushion and feel the tension in the back of the neck and the upper back; (9) Step 10: to exercise the muscles of the front neck. Draw the head to the front and sink the chin into the chest to feel the tension in the front neck; (10) Step 11: to exercise the muscles of the back. Lift the body from the back of the chair. Bend the back, tighten the chest, hold for 10 seconds, and release. Lay down the body on the chair while straightening the muscles; (11) Step 12: to relax the muscles of the chest. Take a deep breath and fill the lungs with air, hold for a few seconds while feeling the tension in the chest and the stomach, and then exhale. After exhaling, breathe normally with relief. Repeat until the difference between tension and relaxation can be felt; (12) Step 13: to exercise the muscles of the stomach. Suck in the stomach, hold for 10 seconds, and release. Repeat the step; (13) Steps 14 and 15: to exercise the muscles of the feet (as in the thighs and calves). Straighten the feet until the thigh muscles become tightened. Then, press the knees together until the tension moves to the muscles of the calves. Hold for 10 seconds, and then release. Repeat each step twice (Rochmawati, 2015). The series of PMR steps above aims to relax and give comforts to the whole body (Sulidah, 2016)

2. Academic stress in the eleventh-grade students in SMA Negeri 8 Makassar before and after PMR

The results of descriptive and statistical analysis showed that before being given the treatment of PMR, students suffered from high level of academic stress. The stress was caused by both external and internal factors. When experiencing high level of academic stress, students felt less enthusiastic and less interested in the learning process; as a result, students' learning outcomes decrease. Thus, PMR was 
necessary. It aimed to release the tension of the tightened muscles and to reduce academic stress in students due to learning in a long period of time. The relaxation hopefully could restore students' enthusiasm for the learning process.

Table 1. Frequency Distribution of Academic Stress in the Eleventh-Grade Students before PMR Treatment was Given

\begin{tabular}{cccccc}
\hline \multirow{2}{*}{ Interval } & \multirow{3}{*}{ Students' Stress Levels } & \multicolumn{3}{c}{ Students' Academic Stress } \\
\cline { 3 - 6 } & & \multicolumn{2}{c}{ Experiment } & \multicolumn{2}{c}{ Control } \\
\cline { 3 - 6 } & & Frequency & $\%$ & Frequency & $\%$ \\
\hline $168-200$ & Very High & 5 & 25 & 6 & 30 \\
$136-167$ & High & 15 & 75 & 14 & 70 \\
$104-135$ & Moderate & - & 0 & - & 0 \\
$72-103$ & Low & - & 0 & - & 0 \\
$40-71$ & & - & 0 & - & 0 \\
\hline & Tery Low & 20 & 100 & 20 & 100 \\
\hline
\end{tabular}

After the treatment was given, different results were obtained. Students' scores increased, signifying that there is a tangible and positive influence of the implementation of PMR. PMR is one of psychological techniques that help reduce physical tension due to stress. In general, students suffering from academic stress are more likely to face problems in the learning process. Thus, PMR needs to be implemented to release students' academic stress at school.
Based on the results of the present study, there was an increase in the average score of students' academic stress as described in the appendix 20. This is because the PMR treatment was given to students who suffered from academic stress. PMR is a muscle relaxation technique that does not require imagination, but focus on the muscle activities by identifying the tightened muscles and releasing the tension to obtain a relaxing sensation (Pratama, 2017)..

Table 2. Frequency Distribution of Academic Stress in the Eleventh-Grade Students after the PMR Treatment was Given

\begin{tabular}{cccccc}
\hline \multirow{2}{*}{ Interval } & \multirow{3}{*}{ Students' Stress Levels } & \multicolumn{3}{c}{ Students' Academic Stress } \\
\cline { 3 - 6 } & & \multicolumn{2}{c}{ Experiment } & \multicolumn{2}{c}{ Control } \\
\cline { 3 - 6 } & & Frequency & $\%$ & Frequency & $\%$ \\
\hline $168-200$ & Very High & - & 0 & - & 0 \\
$136-167$ & High & - & 0 & 2 & 10 \\
$104-135$ & Moderate & 5 & 25 & 12 & 60 \\
$72-103$ & Low & 13 & 65 & 6 & 30 \\
$40-71$ & & 2 & 10 & - & 0 \\
\hline & & 20 & 100 & 20 & 100 \\
\hline
\end{tabular}

3. Effects of PMR on academic stress in the eleventh-grade students in SMA Negeri 8 Makassar

The study results indicated that there was a significant difference between the students given the PMR treatment (experiment group) and the students not given the PMR treatment (control group). In the implementation of PMR, students' interest in learning grew, which can be seen from students' high enthusiasm in taking part the PMR treatment.
This is in line with a study by Nurcahyani $\&$ Fauzan (2016), which found that the $\mathrm{T}$ value was -2.032 with a significance level of $0.042<$ 0.05 , meaning that PMR is an effective relaxation technique to reduce academic stress in high school students. Furthermore, a study by Hidayat (2018) found that there was a significant decrease of anxiety levels in the intervention group after the PMR therapy was given. The PMR therapy can be applied to reduce students' anxiety levels in dealing with competence tests. 
Based on the results of the present study, students' academic stress levels declined after the PMR treatment was given, shown by the significant difference of the mean values between the pretest and the posttest. The results of data analysis indicated that the hypothesis stating that there is no difference in students' high level of academic stress before and after PMR is not proven. However, the results of the present study showed that the hypothesis stating that there is a difference in students' academic stress level before and after PMR is proven. Because the probability was $0.000<0.05$, the first hypothesis was rejected, meaning that that there is a significant difference in students' high level of academic stress before and after PMR. Students' academic stress level was higher before the PMR treatment was given.

According to Utami (2001 and Rochmawati (2015), besides lowering academic stress level, PMR is also useful for: (a) decreasing students' excessive reaction due to stress; (b) reducing the risks of hypertension, headaches and insomnia; (c) lowering anxiety level. Studies have shown that individuals with high anxiety level showed positive physiological effects after performing relaxation; (d) diminishing the risk of stress-related disorders and controlling anticipatory anxiety before the situations that can cause anxiety, such as facing an upcoming examination; (e) reducing negative behaviors usually done during stressful periods, such as smoking, consuming alcohol, taking drugs, and overeating; (f) increasing individuals' enthusiasm in performing daily activities; $(\mathrm{g}$ ) overcoming fatigue as well as delayed mental and physical activities more quickly; (h) improving awareness of a person's physiological state as a result of the emergence of physiological stimuli; (i) increasing self-esteem and self-confidence as a result of increased control of reactions to stress; and (j) improving interpersonal relationships. Relaxed individuals can think rationally in difficult interpersonal situations.

The success of the PMR implementation in reducing students' academic stress can be observed from the students' enthusiasm and interests in the learning process that can result in better learning outcomes. The results of the study suggest that school counselors can take advantage of PMR in giving guidance and counseling service to students who are having problems. It can be denied, however, that challenges were inevitable in the implementation of PMR in the field; one of which is that students were not quite serious to follow the PMR steps demonstrated by the researcher.

\section{CONSLUSION AND SUGGESTION}

It can be concluded that (1) the PMR to deal with students' stress level was implemented in accordance with the steps previously designed; and (2) the students' academic stress in the experiment group were at the very high and high levels before the PMR treatment was given. Likewise, students' academic stress in the control group was in the very high and high categories. However, after the PMR treatment was given, students' academic stress decreased, indicated by the average scores and percentages. Meanwhile, the control group who only received classical guidance also experienced a declining level of academic stress although it was not quite significant; and (3) PMR played a role in reducing academic stress levels of the eleventhgrade students in SMA Negeri 8 Makassar.

With reference to the conclusions above, suggestions are formulated as follows: (1) school counselors can use this study as an input in dealing with students' problems, especially academic stress, and can handle students' problems through proper programs and collaborations with related parties; (2) school personnel should collaborate with school counselors in addressing problems faced by students, especially in reducing students' academic stress in order to achieve better learning outcomes; and (3) future researchers can use this study as a reference to conduct a further investigation into the efforts to overcome students' academic stress.

\section{REFERENCES}

Al-Gamal, E., Alhosain, A., \& Alsunaye, K. (2018). Stress and coping strategies among Saudi nursing students during clinical education. Perspectives in psychiatric care, 54(2), 198-205.

Arioka, N. W. (2018). Pro Kontra Wacana Full Day School. Jurnal Studi Kultural, 3(1), 1-5.

Aryani, F. (2016). "Stres Belajar" Suatu Pendekatan dan Intervensi Konseling". Palu: Edukasi Mitra Grafika.

Baharun, H., \& Alawiyah, S. (2018). POTENSIA: Jurnal Kependidikan 
Islam. Pendidikan Full Day School Dalam Perspektif Epistemologi Muhammad 'Abid Al-Jabiri, 4(1), 1-22.

Barseli, M., \& Ifdil. (2018). Konsep Stres Akademik Siswa. Jurnal Konseling dan Pendidikan, 5(3), 143-148.

Chitra, K. (2018). Effectiveness of audioassisted teaching module of progressive muscle relaxation technique on level of stress among visually impaired adolescents in selected school for visually impaired at Dehradun. International Journal of Medical Science and Public Health, 7(8), 601605.

Corey, G. (2015). Theory \& Practice of Group Counseling, Ninth Edition. Australia: Brooks/Cole Cengage Learning.

Erford, B. T. (2016). 40 Techniques Every Counselor Should Know. Yogyakarta: Student Library.

Gangadharan, M. P., \& Madani, M. A. H. (2018). Effectiveness of Progressive Muscle Relaxation Techniques on Depression, Anxiety and Stress among Undergraduate Nursing Students. Int $J$ Health Sci Res, 8(2), 155-63.

Hidayat, A., \& Sahruddin, A. (2016). Locus of Control in Late Adolescence: Characteristics and Ability of New Students to Overcome Depression. GUIDENA: Jurnal Ilmu Pendidikan, Psikologi, Bimbingan dan Konseling, 6(2), 172-179.

Hidayat, E. (2018). Pengaruh Terapi Relaksasi Progresif Terhadap Penurunan Tingkat Kecemasan Dalam Menghadapi Uji Kompetensi Mahasiswa Tingkat III Akper Muhammadiyah Cirebon. Jurnal Keperawatan Soedirman, 12(2), 93101.

Hidayat, I., \& Ilyas, A. (2019). Efektivitas Relaksasi Otot Progresif Untuk Mereduksi Stres Akademik Siswa Sebagai Teknik Dalam Layanan BK. $e$ Journal Pembelajaran Inovasi, Jurnal Ilmiah Pendidikan Dasar, 7(1).

Idris, I. (2018). Efektivitas Problem Focused Coping Dalam Mengatasi Stress Belajar Siswa Pada Pelajaran Matematika. Jurnal Psikologi Pendidikan \& Konseling, 4(1), 63-68.

Karyo, V. S., \& Saraswati, I. (2017). Karyo, Vitriyanti Sukarno, and Ina Saraswati. "Counseling, Progressive Relaxation, and Writing a Journal to Reduce General Anxiety Disorder Symptoms in an Undergraduate Student from Universitas Indonesia. 1st International Conference on Intervention and Applied Psychology (ICIAP 2017). Atlantis Press.

Maghfirah, S. (2015). Relaksasi Otot Progresif Terhadap Stres Psikologis dan Perilaku Perawatan Diri Pasien Diabetes Mellitus Tipe 2. Jurnal Kesehatan Masyarakat, 10(2), 137-146.

Merakou, K., Tsoukas, K., Stavrinos, G., Amanaki, E., Daleziou, A., Kourmousi, N., et al. (2019). The Effect of PMR on Emotional Competence: DepressionAnxiety-Stress, Sense of Coherence, Health-Related Quality of Life, and Well-Being of Unemployed People in Greece: An Intervention Study. EXPLORE, 15(1), 38-46.

Nurcahyani, I., \& Lutfi Fauzan. (2016). Efektifitas Teknik Relaksasi dalam Konseling Kelompok Behavioral untuk Menurunkan Stres Belajar Siswa SMA. Jurnal Kajian Bimbingan dan Konseling , Vol 1, No 1, Hal 1-6.

O'Donnell, Patrick, S., \& Linda, L. (2019). Teacher acceptability of PMR in the classroom for the treatment of test anxiety. Journal of Psychologists and Counsellors in Schools, 1-15.

Pitt, A., Oprescu, F., Tapia, G., \& Gray, M. (2018). An exploratory study of students' weekly stress levels and sources of stress during the semester. Active Learning in Higher Education, 19(1), 61-75.

Pratama, B. (2017). Pengaruh Relaksasi Otot Progresif Terhadap Penurunan Tingkat Kecemasan Pada Ibu Bersalin Fase Laten Di Rsu Pku Muhammadiyah Bantul Yogyakarta. Yogyakarta: STIKES Jenderal Achmad Yani Yogyakarta.

Rahmawati, W. (2017). Efektivitas Teknik Restrukturisasi Kognitif untuk Menangani Stres Akademik. Jurnal Konseling Indonesia, 2(1).

Resti, I. (2014). Teknik Relaksasi Otot Progresif Untuk Mengurangi Stres Pada Penderita Asma. Jurnal Ilmiah Psikologi Terapan, 01-20.

Ribeiro, I. J., Pereira, R., Freire, I. V., de Oliveira, B. G., Casotti, C. A., \& Boery, 
E. N. (2018). Stress and quality of life among university students: A systematic literature review. Health Professions Education, 4(2), 70-77.

Rochmawati, D. H. (2015). Teknik relaksasi otot progresif untuk menurunkan kecemasan. Nurscope, 1-20.

Sari, A. P., \& Falah, I. F. (2018). Perbedaan Stress Level Siswa Sekolah Dasar Antara Full-Daydan Half-Day School di Kabupaten Kuningan. urnal Ilmiah Educater, 4(2), 142-148.

Sulidah. (2016). Pengaruh Latihan Relaksasi Otot Progresif Terhadap Kualitas Tidur Lansia. Jurnal Keperawatan Padjadjaran, 4(1).

Suryono, Triyono, \& Handarin, D. (2016). Keefektifan Teknik Relaksasi untuk Menurunkan Stres Akademik Siswa SMA. Jurnal Pendidikan Humaniora, 4(2), 115-120.

Tollefson, M., Kite, B., Matuszewicz, E., Dore, A., \& Heiss, C. (2018). Effectiveness of Student-Led Stress Reduction Activities in the Undergraduate Classroom on Perceived Student Stress. College Student Journal, 52(4), 505-515.

Tyani. (2015). Efektifitas Relaksasi Otot Progresif Terhadap Tekanan Darah Pada
Penderita Hipertensi Esensial. Jurnal Online Mahasiswa (JOM) Bidang Ilmu Keperawatan, 2(2), 1068-1075.

Utami, M. (2001). Prosedur-Prosedur Relaksasi, dalam Subandi, M.A., Psikoterapi Pendekatan Konvensional dan Kontemporer. Yogyakarta: Unit Publikasi Fakultas Psikologi UGM \& Pustaka Pelajar.

Utami, S., \& Nasution, N. (2018). Pengaruh Pemberian Teknik Relaksasi Otot Progresif Terhadap Tingkat Stres Dalam Menyusun Skripsi Pada Mahasiswa Keperawatan Semester Viii Di Universitas Batam. Jurnal Zona Keperawatan, 8(3), 69-70.

Yu, S. Y., \& Suh, E. E. (2019). Conditional Effect of Years Employed in Selfefficacy and Stress among Studying Clinical Nurses: An Exploratory Mixed Method Study. Korean Journal of Adult Nursing, 31(3), 303-314. 